Ivana Žužul

ivana.zuzul@inet.hr

\title{
Imagi/nacija. \\ Neoromantičarski koncepti imaginacije u tekstovima hrvatskog narodnog preporoda i u pjesništvu Domovinskog rata
}

ABSTRACT. Žužul Ivana, Imagi/nacija. Neoromantičarski koncepti imaginacije u tekstovima hrvatskog narodnog preporoda i u pjesništvu Domovinskog rata (Neo-Romantic concepts of imagination in Croatian National Revival writings and in Croatian War of Independence poetry). „Poznańskie Studia Slawistyczne” 1. Poznań 2011. Rys Press, pp. 291-318. ISSN 2084-3011.

The paper attempts to shed light on the concept of imagination and its formative role in imagining collective identities such as gender, religion or nation in literary, journalistic and programmatical texts written by Croatian revivers, as well as in the poetry of the Croatian War of Independence. Here, the concept of imagination is conceived as a field criss-crossed by contradictions selectively used by the revivers and contemporary Croatian poets in the 1990's, in order to achieve certain political goals. According to need, they use it to reconcile resemblances with differences, general with particular or else for the purpose of generating hegemonistic symbols or organic unity of culture/nation, they erase divisions, ignoring and abolishing othernesses.

Keywords: Croatian National Renaissance, Croatian War of Independence poetry, romantic imagination, politics of identity, nation. 


\section{Imaginacija u službi začeća nacije}

Romantičarski koncept imaginacije zaokupljao je pozornost mnogih suvremenih mislilaca. Od vremena kad je Maurice Bowra prvi put objavio svoju čuvenu studiju The Romantic Imagination 1950. i Abrams svoj neizbježni priručnik o razvoju romantičkih teorija percepcije i imaginacije The Mirror and The Lamp 1953. do danas mnogi teoretičari dotaknuli su se tog problema. Naravno da se obzor proučavanja tijekom vremena mijenjao. Kako su različita vremena i mjesta oblikovala različite koncepte imaginacije, tako su i uspostavljala različite tipove identiteta $^{1}$. Bowra je već prije više od pola stoljeća komentirao neporecivu konstitutivnost imaginacije u oblikovanju pjesničkog sebstva:

Vjerovanje u imaginaciju bilo je dijelom ondašnjeg vjerovanja u individualno sebstvo. Pjesnici su bili svjesni čudesnog kapaciteta za kreiranje imaginarnih svjetova, i nisu mogli vjerovati da je on ništavan ili pogrešan. Upravo suprotno smatrali su da bi njegovo kroćenje značilo poricanje nečega vitalnog i nužnog njihovom cijelom biću².

Ta grozničava vjera u imaginaciju obilježila je i samopredodžbu vlastite kulturne djelatnosti hrvatskih preporoditelja. No čini se da oni tu projekciju nisu stvarali samo da bi potvrdili sebe i da bi veličali samu umjetnost bez ostatka, ona je trebala zaposjesti i nekog drugog. Poput drugih suvremenih teoretičara i Timothy Clark bez susprezanja govori o proturječnostima i tranzicijama romantičarskog i postromantičarskog koncepta imaginacije:

Arhaično shvaćanje nadahnuća kao naredbe drugog preoblikovano je u humanistički kult koji pretpostavlja drugost u nama samima, izvor skrivene moći i transformacija. Takvi pokušaji

1 Identitet se ovdje kao pojam svakako stavlja u okvir fikcionalnosti, dakle promatra se kao konstruktivna kulturalna tvorba. No, iako se time u navodnike stavlja jednoznačnost, samorazumljivost i fiksnost identiteta, ne dovodi se u pitanje njegova politička vjerodostojnost ili djelotvornost.

2 M. Bowra, The Romantic Imagination, London 1961, str. 1-2. Prijevodi navoda iz neprevedenih studija su moji. 
da se pronađe neki povlašteni unutarnji izvor autoriteta, providnosti ili transcendentnosti često su u funkciji liberalne retorike samooslobađanja i samootkrivanja. Ipak, kao što smo vidjeli, shvaćanje nadahnuća kao performativa koji (nemoguće) utemeljuje svoju vlastitu vrijednost, često se izražavalo pojmovima koji proturječe eksplicitnoj misli o samopotvrđivanju, drugim riječima kao proleptička slika nepredviđenog učinka teksta na druge, izmaštanu publiku. Koncepti nadahnuća kao forme nadsubjektivnosti ili kreativnosti u Wordswortha, Shelleya, Hölderlina, Nietzschea i drugih ipak svjedoče o potrebi za odgovorom drugog kojeg su se naizgled, na površini, odrekli. Romantičarske filozofije stvaranja pounutarnjile su usmene i retoričke modele neposredne komunikacije kako bi konstruirale idealizirano shvaćanje usamljenog čina pisanja koji izostavlja njegovu u velikoj mjeri posredovanu narav i neizvjestan učinak. $^{3}$

Koncept imaginacije, dakle, nije oslobođen proturječnosti. On je samo naizgled nevin i nezaokupljen učinkom na druge. Zato i ne čudi činjenica da su ga preporoditelji, u svojim književnim, publicističkim i programatskim tekstovima, isprepleli s politikama nacionalnog identiteta. Kad je riječ o preporoditeljima, treba napomenuti da postrani nisu ostale ni politike drugih kolektivnih identiteta poput religijskog ili pak rodnog sa svim nezakonitostima, nečistoćama i arbitrarnostima koje su nužno u njih upisane. Sprega imaginacije i politike u postizanju zajedničkog cilja - onoga što se na prvi pogled čini nezamislivim ili nespojivim - svakako je prisutna u radu preporoditelja. Čini se da njihov koncept imaginacije s jedne strane poseže za romantičarskom predodžbom, u kojoj pisac piše navođen svojevrsnom Providnošću i ne zna za koga točno piše, ali i za nacrtom u kojem projicira svoju vlastitu publiku. Takvu „dvoličnost”, koja se ovdje pripisuje preporoditeljskoj imaginaciji, suvremeni teoretičari odavna su prepoznali u romantičarskoj estetičkoj ideologiji. Imaginacija je ondje svojevrstan trbuhozborac Genija, Boga, i ne može se dosegnuti individualnim silama ili kreativnošću autora, a opet baš u te sile i u tu kreativnost romantičari najviše vjeruju. Takva

3 T. Clark, The Theory of Inspiration. Composition as a crisis of subjectivity in Romantic and post-Romantic writing, Manchester - New York 2000, str. 282-283. 
dualistička imaginacija koja spaja spontani genij i individualno pregnuće, samorealizaciju u apsolutu i slobodu odabira, kao što je već naznačeno, obilježava i rad hrvatskih preporoditelja. Imaginacija je i u njih svojevrsno proturječno planiranje nepredvidivog. Današnji suvremeni teoretičari romantizma oskvrnjuju sliku imaginacije kao neinhibirane kreativnosti progovarajući o njezinim proturječnostima:

Hölderlinov koncept proračunatog nadahnuća zvuči kao oksimoron. Ustvari, on može služiti kao naslov zanemarene tradicije shvaćanja nadahnuća kao pomno proučenog, planiranog ili kultiviranog delirija - umjetno izazvane moći Tajanstva, srodnog ludilu ili stanju sanjarenja, uključujući možda droge (kao u Baudelaireovu eksperimentiranju s hašišem), ali u konačnici nadahnuća sui generis i nesvodivog na reduktivne kategorije kojima bi medicina opisala nenormalna psihička stanja ${ }^{4}$.

Na ovom tragu, zanima nas, dakle, preporoditeljski koncept imaginacije kao strategije zamišljanja kolektivnih identiteta (roda, nacije, religije).

Strastvena odanost romantičara političkim ciljevima, kako se ističe u recentnim studijama posvećenima romantizmu, nije rijetkost. Korištenje imaginacije i uopće kulturnih sadržaja romantičarskih pisaca u svrhu onoga što Anderson naziva ,zamišljanjem zajednice” u prvoj polovini 19. st. vrlo je raširena europska pojava. Poput romantičara i hrvatski preporoditelji upravo su zahvaljujući snažnom investiranju u imaginaciju postali nositelji društvenih promjena. Uz njezinu pomoć zakrpali su trajni problem osobnog zaborava, selektirali ili izmislili povijest, uskrsavali mitove nacionalne povijesti, osnaživali rodne stereotipe udarajući temelje zamišljenoj zajednici.

Upravo u to vrijeme opće mjesto romantičarskog pogleda na svijet postaje njihovo zanimanje za povijest. Ono nije izostalo ni u slučaju hrvatskih preporoditelja. U romantičarskoj maniri imaginacijom se slaže mozaik prošlosti - ponovno se otkriva istina koja je bila iz raznoraznih okolnosti neopravdano zaturena. Oživljavanje točno određenih epizoda iz srednjovjekovne povijesti, obnavljanje pučkih običaja i uopće pučke kulture, uspostavljanje kontinuiteta s usmenom književnošću, sve su to

4 Ibidem, str. 116. 
bile imaginacijske reprezentacijske strategije pomoću kojih se oblikovao fikcionalni nacionalni identitet kao stvaran, iskonski i nepromjenjiv. Ovdje ćemo se ponajprije usredotočiti na one strategije zamišljanja koje su funkcionirale kao identitetska uporišta.

Jedna je od najčešće komentiranih identitetskih strategija u našoj historiografiji i književnoj povijesti imaginiranje imena predaka, odnosno zajedničkog staroilirskog podrijetla Južnih Slavena. Da je ime osobito važan uvjet opstojnosti bilo kojeg identiteta i transformacija njegova zamišljanja, ne treba posebno isticati ${ }^{5}$. Na određeni način i preporoditelji su se prema imenu, osviješteno ili ne, odnosili kao prvoj vanjskoj oznaci opstojnosti identiteta. U njihovoj predožbi ime je bilo nužno za gradnju identiteta neke vječne, i stare i nove, zamišljene zajednice te za potvrđivanje homogenosti identiteta vlastite skupine. Zajedničko objedinjujuće ime na krilima imaginacije trebalo je ponajprije poništiti njihove estetske i poetički heterogene tekstove te stavove da bi, živeći novu kulturu a ujedno i imaginirajući je, udarilo temelje nacije.

Vlastito djelovanje jedan od vodećih preporoditelja, Janko Drašković, 1838. imenovao je ,najnovijim književnim preporodom naše domovine”, a prvi povjesničar pokreta, Ivan Milčetić, razdoblje od 1835. do 1850. označio je 1878. kao „doba preporoda, ili ti, po imenu doba ilirsko"6. Iz imenovanja vlastitog pokreta očito je da je u preporoditeljskoj terminologiji književni preporod značio buđenje, procvat i preobražaj domovine. U tom su smislu preporoditelji podrazumijevali

5 Upravo tog problema, doduše na primjeru imena Europe, dotiče se i Balibar u svojoj studiji Mi građani Europe: „Postojanost imena uvjet je svakog «identiteta». Borimo se za određena imena i protiv drugih, kako bismo ih prisvojili (Europa, Jugoslavija, Kosovo, Makedonija, ali također i Francuska, Velika Britanija, Njemačka). Sve te borbe ostavljaju tragove, u obliku nostalgičnih priželjkivanja i granica ili utopija i transformacijskih programa. Prema tome, ime Europe - izvedeno iz daleke antike i isprva dodijeljeno maloj pokrajini Male Azije - povezano je s kozmopolitskim projektima, zahtjevima za imperijalnom hegemonijom ili s otporom koji su oni izazvali, s planovima dijeljenja svijeta i širenja «civilizacije» čijim se čuvarima smatraju kolonijalni moćnici, sa suparništvom «blokova» koji se prepiru oko pravovaljanosti njihova posjedovanja, sa stvaranjem «pojasa blagostanja» sjeverno od Sredozemlja, «velike moći u dvadeset i prvom stoljeću»", u: É. Balibar, We, the People of Europe? Reflections on Transnational Citizenship, Princeton - Oxford 2001, str. 9-10.

6 Usp. studiju Hrvatski narodni preporod, Ilirski pokret, ur. J. Šidak, V. Foretić, J. Grabovac, I. Karaman, P. Strčić i M. Valentić, Zagreb 1988, str. 119. 
da je imaginacija proces dosezanja ultimativne realnosti. Štoviše, poput Coleridgea, preporoditelji umjetniku/književniku pripisuju zadaću transformiranja vanjskog svijeta ${ }^{7}$. Imaginacija je s jedne strane preporoditeljima bila u nekoj esencijalnoj vezi s političkim djelovanjem, a s druge strane bila je predstavljena kao nešto sveto, proročansko i nepragmatično. Dobar primjer pronalazimo u programatskom tekstu gdje je ime domovine predstavljeno kao nešto ustoličeno od pamtivijeka, božansko, ali i doslovno materijalizirano kao ono od čega se što gradi:

Ime otačbine jest světo, jer u njoj sam Bog obitava i njegova misao od věka. Ime deržave, kao n. p. carevinah, kraljevinah, jest takodjer sveto, jerbo u njima stanuju ljudi ljubeći nada sve Boga i bližnjega svojega; ali opet ime otačbine jest preko svega najsvetie. (...) Kada tko kuću zidati hoće, pripravlja najprie nužnu gradju. (...) Kuća se diže. Jedan daje cigle, drugi zida, treći pili dèrva, a četvèrti udaljen stojeći spravlja gradju. Stoji kuća lěpa, uznosita. Svi susědi i inostrani putnici prolazeći polag, raduju se, govoreći: da lěpe nove kuće! Kuća je ta otačbina naša, - gradja je misao božja u otačbini našoj živeća, - rabotnici, domorodci, - udaljeni, naši pobratimci, ostali Slavjani; - putnici pako značu inostranci, naši bližnji i dalji susědi ${ }^{8}$.

Imaginacija je ponovno rasuta između božanske vječnosti otadžbinskog imena i potrebe da se ono, poput kakve kuće, doslovno izgradi. Ime je evokativan simbol (Assmann) - svetinja naroda te ima ulogu svojevrsnoga nacionalnog spomenika. Ono što je u toj priči paradoksalno je to da se petrificirani nacionalni spomenik poput imena otadžbine, kojem se stranci trebaju diviti, mora konstruirati. Aleida Assmann ime smatra jednim od nacionalnih spomenika kojim se u 19. st. uprizoruje prošlost:

Istorija spomenikâ posebno dobro ilustruje šta zapravo znači stvoriti kolektivni identitet vezivanjem za zajedničku prošlost

7 Usp. Imagination, u: A dictionary of modern critical terms, ur. R. Fowler, HenlyBoston 1973, str. 93.

8 Dragutin, Svět pismeni i nepismeni, Danica ilirska, br. 46, 13. studenoga 1847, str. 184, u: Danica ilirska 1847-1848-1849, Zagreb 1972. 
i obavezivanjem na zajedničko sjećanje. Spomenici oličavaju prošlost u reljefima, frizovima, alegorijama, figurama i imenima. Oni su ,čas istorije pretvoren u kamen” (...) U žanru spomenika istorija postaje instrument politike. Istorijsko obrazovanje sprovodi se stvaranjem nacionalnih mitova9

Imaginiranjem imena domovine, koje se nije preklapalo s imenom države (Monarhije) u kojoj su preporoditelji djelovali, oživljavali su točno određenu prošlost, kujući njome paradoksalno budućnost. Oni su naime, prema mišljenju Mirjane Gross, vjerovali da je nacija postojala i prije njezine uspostave u 19. st. i zato su ime Ilir i imaginirano zajedničko podrijetlo svih Južnih Slavena kao i ime domovine koristili za zamišljanje transnacionalne zajednice u kojoj bi opet nezamislivo zajedništvo jačalo zasebnost ${ }^{10}$.

I poetski uradci preporoditelja funkcioniraju na isti način. Kao što ćemo vidjeti i u Demetrovu slučaju, čini se da je imaginacija i za njega isprepletena ne samo s prošlošću nego i sa sadašnjošću. Njezina dvostrukost izražena je i ovdje jer iako tipično romantičarski, utopijski, oživljava umrlu prošlost, ona doista u stvarnosti polučuje vjerovanje svojih sunarodnjaka u zajednicu u nastajanju: „I starom će slavom ime / Opet sinut ILIRIE, / I dičit se rod tvoj njime / Kako se je dičio prie. // Zato stresi pepeo s glave / Ilirio, i nad grobom / Nekadašnje tvoje slave, / Neplač više: Bog je s tobom!'"11. U posljednjem navedenom

9 A. Assmann, Rad na nacionalnom pamćenju. Kratka istorija nemačke ideje obrazovanja, Beograd 2002, str. 52.

10 Gaj je tu proturječnu ideju iznio u Proglasu za pérvu polovinu deveto-godišnjega tečaja 1843 Narodnih ilirskih novinah i Danice ilirske: „Ilirski su domorodci svojimi dĕli pokazali, da oni svaki svoju: Horvat horvatsku; Slavonac slavonsku; Sèrbljin sèrbsku, a svi skupa obćenitu domovinu svoga naroda bez razlike imenah, věrozakonah, vladanja, i ostalih posebnostih vèrhu svega ljube i da po ilirskoj slozi ništa drugo nežele postići, nego baš to, da svaki, bratinskom ljubavi objačen sve svoje občuva i uzdèrži. Dakle po ilirstvu brat Horvat da uzdèrži ne samo svoje ime, nego sve ono, što je horvatsko; po ilirstvu brat Slavonac da uzdèrži ne samo svoje ime, nego sve ono, što je slavonsko; po ilirstvu brat Sèrbljin da uzdèrži ne samo svoje ime, već sve ono što je sèrbsko". Preuzeto iz: Danica ilirska 1841-1842-1843, Zagreb 1971 stranice nisu naznačene.

11 D. Demeter, Utěha Ilirii prigodom proglašenja Sàrbskoga ustava na Kale-mejdanu izpod Bĕograda na Todorovu subotu dana 11/23 Veljače (Feb.) 1839, Danica ilirska, br. 
stihu Demeter pokušava ucijepiti vjerovanje da je oblikovanje etniciteta potpomognuto Božjom providnošću koja budućnosti jamči blagostanje negdašnje prošlosti.

Već iz ovih primjera, koji nisu usamljeni, vidi se da preporoditelji imaginaciju uprežu u nešto što Hobsbawm naziva trima modelima „izmišljanja tradicija”:

a) one koje uspostavljaju ili simbolizuju socijalnu koheziju ili članstvo u grupi, stvarne ili veštačke zajednice, b) one koje uspostavljaju ili legitimiziraju institucije, status ili odnose identiteta $\mathrm{i}, \mathrm{c}$ ) one čiji je osnovni cilj bio socijalizacija, ,usađivanje verovanja, sistema vrednosti i konvencija vezanih za ponašanje. Dok su tradicije tipa b) i c) svakako bile isplanirane (...) uz oklevanje se može sugerisati da je tip a) bio prevladavajući, a da su druge funkcije smatrane kao implicitne, ili kao da proizlaze iz osećaja identifikacije sa „zajednicom”, i/ili institucijama koje je predstavljaju, izražavaju ili simboliziraju, kao što je „nacija”"12.

Imaginiranje imena u preporoditelja, kako se vidjelo u gore navedenim primjerima, ispunjava zadaće gotovo sva tri Hobsbawmova modela. Zbog iznimno snažne simboličke uloge imena u tekstovima Hrvatskoga narodnog preporoda, važno je imaginirati priču o njemu, jer se upravo njime uspostavlja nevidljiva povezanost između članova zamišljene zajednice. Ime kao amblem utjelovljuje i sudjeluje u konstituiranju kanona zajedničke prošlosti. Ta izmaštana tradicija postaje neotuđivom sastavnicom kolektivnog identiteta a u rukama preporoditelja postaje političko oruđe.

Ime je, dakle, ključan element nacionalnog identiteta i zbog toga su „bitke” za njega tako gorljive. U njima se kolektivni identitet oblikovao i preobražavao. Drevno ilirsko ime, kao oznaka nacionalnog bića, ostalo je isto tek na nominalnoj razini. Njegova su se značenja, međutim, pod pritiskom konkretnih ideoloških potreba vremena znatno preoblikovala. U gradnji hrvatskoga nacionalnog jedinstva mitska dugovječnost ilir-

12, 23. ožujka 1839, str. 46, u: Danica ilirska 1838-1839-1840, Zagreb 1970.

12 E. Hobsbawm, Uvod: Kako se tradicije izmišljaju, u: Izmišljanje tradicije, ur. E. Hobsbawm i T. Ranger, Beograd 2002, str. 17-18. 
skog imena rascjepkano je etničko tijelo pretvarala u snažnu objedinjenu zajednicu. Na primjeru zamišljanja imena čini se da je imaginacijski koncept preporoditelja nerazmrsivo upleten u oblikovanje i preoblikovanje kolektivnog identiteta.

Svi dostupni nacionalni simboli poput imena, stvarni ili imaginirani, bili su dobrodošli u upornoj preporoditeljskoj agitacijskoj borbi u kojoj se je pojedinac mogao u svojoj punini realizirati tek aktivnim sudjelovanjem u gradnji etničke zajednice. Egzistenciju individualnog identiteta omogućuje kolektivni identitet, a da bi sunarodnjaci hrvatskih preporoditelja usvojili to vjerovanje, oni su ispjevali brojne stihove u čast bitke na Grobničkom polju koja se, kako tvrdi Žanić u svojem prilogu zborniku Historijski mitovi na Balkanu, nije ni dogodila ${ }^{13}$. U tom sveprisutnom motivu u tekstovima preporoditelja ${ }^{14}$ nisu ispremreženi samo individualni i kolektivni identitet, nego i religijski. Religijsko se isprepleće s nacionalnim kako bi se svi pripadnici zajednice uvjerili da je žrtva individualnog identiteta vrijedna kolektivnog. U konačnici, preporoditelji na taj način poručuju: da nije bilo grobničkih Ilira koji su na istoimenom polju uništili Tatare, ne bi bilo ne samo Ilira-preporoditelja nego ni i Europe. Taj događaj Demetru je reprezentativan po svojem nacionalnom potencijalu. Njega samo nadopisuje i osnažuje religijskim idejama u čuvenom romantičarskom spjevu Grobničko polje: „Svak' ovamo! kom' je Ilirka život dala, / Našeg roda to je sveta Meka, / Čiste kèrvi dědah naših rěka / Tu je okaljanu světa čest oprala! / Svojim kraljem tu sve Hèrvat spase kralje, / Batukani kameni su ovi / Strašni bili stupovi Herkulovi, / Gdi upisa udes: Do tuda ne dalje! / Tu nek Hèrvat uči, koja mu je cĕna, / Tu nek cèrpi hrabrost, ponos, volju, / Nek ne ište věk utěhu bolju, / Neg koju mu daje ova uspomena!!"15 Lokalitet, i to ne bilo koji nego onaj s osobitim nacio-

13 I. Žanić, Simbolični identitet Hrvatske u trokutu raskrižje-predziđe-most, u: Historijski mitovi na Balkanu, ur. H. Kamberović, preveo S. Kreso, Sarajevo 2003, str. 161-202.

14 Ilustrirat ću to s nekoliko primjera. Nemčić obrađuje motiv i u Putositnicama i u zasebnoj pjesmi Pobratimom u ilirstvu, Demeter u svom spjevu Grobničko polje, Preradović u pjesmi Na Grobniku, Kukuljević u Dopisu iz primorja, Trnski u pjesmi Smàrt Ilira na grobničkom polju.

15 D. Demeter, Izabrana djela, prir. N. Batušić, Zagreb 1997, str. 84. 
nalnim mogućnostima, Demeter je pretvorio u najsvetije mjesto, našu Meku. Sakralizaciju prostora i bitke u Izjasnjenjima k Grobničkom polju dodatno ojačava:

Velika je misao: polje, koje sada moja noga gazi, to je ono polje, gdi su moji praotci najvećeg i najmogućnieg nepriatelja kèrštjanstva i prosvěćenja uništili; na tom polju su oni pokazali, što je šaka odvažnih, slobodnih ljudih kadra učiniti, kada š njimi samo sloga vlada; na tom polju radilo se je o tom: da ugarsko kraljestvo propadne za uvěk, ili da se opet digne. Hèrvatski mač nadvlada, i ugarsko kraljevstvo dignu se opet iz svojih razvalinah. To čuvstvo opisati se ne da, to je svemoguće, to je sveto! Do duše ovo polje zaslužilo bi prosti ali gorostasni spomenik - kao što je bio čin, koi se je jednom na njemu sbio, da se svaki putnik spomene, da je sveta zemlja, koju gazi! To su učionice narodnosti, narodnog ponosa, junačtva - i vrědne najvećih žèrtvah ${ }^{16}$.

Sakralizacijom mjesta Demeter nije posvetio samo nacionalni nadidentitet nego ga je učinio izuzetno lijepim, onim za čim treba žudjeti, onim što je u romantičarskom duhu pomalo sablasno i vrijedno najvećih žrtava. Aleida Assmann ističe da je uloga takvih spomenika da ,pretoče ideju nacije u čulni oblik i da joj pridaju auru numenalnog. Nacionalni spomenici su svetilišta, mesta na kojima pojedinac može da učestvuje u kultu nacije i da oseti jezu od onog najsvetijeg" "17. Svetost i mjesta i događaja u funkciji je pobuđivanja domorodnih osjećaja svih pripadnika zamišljene zajednice. Njezine granice nisu čvrste i jasne, mogu se osporiti ili promijeniti. Imaginacija je ona sila koja crta granice prikazujući tu bitku presudnom ne samo za hrvatske zemlje u okviru Monarhije nego i za cijelu Europu. Kiteći se amblemom Grobnika, hrvatski teritorij, dakle, postaje konstitutivnim za projekt Kraljevine Ugarske. Realna politička borba odvija se mahom u području imaginacije, ali njezina moć nije nimalo bezazlena. Unatoč pomanjkanju materijalnih dokaza o autentičnosti događaja, preporoditelji se bez

16 Ibidem, str. 104.

17 A. Assmann, Rad na..., op. cit., str. 51. 
suzdržavanja identificiraju s ,grobničkim Ilirima” prikazujući (tuđi) zamišljeni identitet kao vlastiti. Individualni identitet u njihovom imaginacijskom konceptu posrće pred kolektivnim, nacionalnim. No ni taj svojevrsni nad-identitet iako dominantan nije homogen, nego je ispresijecan individualnim, religijskim i drugim dijelom potisnutim identitetima čije su međusobne granice potpuno zamućene.

Granice rodnog identiteta u imaginacijskom konceptu pojedinih preporoditelja obično su se prekrajale prema nacionalnom Nad-identitetu. Ferber tvrdi da je imaginacija žene u europskom romantizmu, pod pritiskom povijesnih lomova, rezervirana za muškarce:

Iako romantičarske vrijednosti i vjerovanja mogu u principu biti jednako atraktivni ženama i muškarcima - predanost života umjetnosti, sjedinjenost sa sublimnim u planinama, zaronjenost u politički aktivizam - sve je to u praksi bilo mnogo teže ženama, osobito onima koje su imale djecu i slabo zdravlje; u Europi je to tek bio početak iščezavanja patrijarhalnog poretka ${ }^{18}$.

Teško je govoriti o tom početku kad je riječ o hrvatskim preporoditeljima. Status feminilnog subjekta oni su imaginirali imajući na umu čvrstu rodnu podjelu rada na nacionalnoj svijesti. Unatoč silini patrijarhalnog poretka, važnost ženine uloge nije poricana u konstrukciji naracije o naciji. Njome se pozabavila Nira Yuval-Davis u studiji Rod i nacija ${ }^{19}$, ustvrdivši da su žene u tom kontekstu oblikovane upravo kao hegemonistički simboli, odnosno kao nositeljice identiteta. Zaviri li se u tekstove hrvatskih preporoditelja i sasvim površno, lako se zamjećuje da lik žene simbolizira

18 M. Ferber, Romanticism. A Very Short Introduction, New York 2010, str. 111.

19 N. Yuval-Davis ženama daje središnju ulogu u nacionalnim previranjima; čak im pripisuje odlučujuću važnost u reprodukciji etničkih i nacionalnih projekata. Teoretičarka promatra žene kao one koje biološki reproduciraju pripadnike etničkih kolektiviteta; one koje reproduciraju granice etničkih/nacionalnih skupina; kao glavne sudionice u ideološkoj reprodukciji kolektiviteta i prenositeljice njegove kulture; označiteljice etničkih/nacionalnih razlika; sudionice nacionalnih, ekonomskih, političkih i vojnih borbi. U svojoj studiji Rod i nacija, N. Yuval-Davis naglasak stavlja na kulturnu reprodukciju čije su aktivne sudionice žene. Pritom poput drugih teoretičara nacije ističe da se kultura ne može pojmiti kao homogena i stalna kategorija, nego kao polje isprepleteno brojnim proturječjima koje različiti društveni akteri koriste selektivno radi postizanja određenih političkih učinaka. 
„duh” kolektiviteta ${ }^{20}$. Domovina ili zamišljena zajednica počesto je personificirana kao majka. Demeter je u Mislima o ilirskom jeziku ,ilirske deržave" primjerice prispodobio majci s ranama ${ }^{21}$, Gaju je pak u njegovoj Kratkoj osnovi... domovina majka ${ }^{22}$, Hrvati njezini sinovi, a drugi Slaveni braća, a i u njegovoj pjesmi Horvatov sloga i zjedinjenje sve je Hrvate rodila jedna mati ${ }^{23}$. Zamišljajući etnicitet kao majku, čuvaricu obitelji, lako se mogu razumjeti žrtve koje su oni koji toj zajednici žele pripadati spremni podnijeti. Mihanovićeva Horvatska domovina, današnja službena himna, posve izravno govori o privlačnosti najveće žrtve koja se polaže na „oltar domovine”: „Veseli se, tužna mati, / Padoše ti vrli sini, / Ko junaci, ko Horvati, / Ljaše krvcu domovini!"24.

Kao što smo već spomenuli, od osamdesetih naovamo kulturne i književne teorije jasno su artikulirale kako je obitelj, kao i svaka druga institucija, stroj za proizvodnju moći, ali i njezina posljedica, te je kao takva u cijelosti interesna zajednica. Uvriježeno mišljenje hrvatskih preporoditelja odraz je tradicionalističke ideje o obitelji-temelju etnije na kojemu se ona gradi kao (navodno) bezinteresna zajednica protkana osjećajima bezrezervne odanosti. Anderson je to u cijelosti opovrgnuo. On tvrdi da je:

20 Natka Badurina u svojoj studiji Nezakonite kćeri Ilirije zamijetila je da se ta metaforika u hrvatskoj preporodnoj književnosti kreće od ranjene i ponižene lijepe žene kakvom je prikazuje Štoos do pobjedničke ljepotice-ratnice u koju je pretvara Trnski; u: N. Badurina, Nezakonite kćeri Ilirije, Hrvatska književnost i ideologija u 19. i 20. stoljeću, Zagreb 2009, str. 47-48.

21 „Huda vremena postigla su ilirske daržave i razorila sve, što je u njih cvalo. Rane od različite ruke proizvedene bacile su našu majku u nesvest, iz koje se ona, probudjena od ljubežljivih glasovah nekih njezinih sinovah, sada stopram pridizati počimlje", u: D. Demeter, Izabrana..., op. cit., str. 173.

22 ,Ako Horvatu premišljavanje nastojne i nevtrudljive marljivosti svojeh bratov slavenskeh osebito Čehov, Lehov i Rusov, z' kojum oni občinski vrt naroda obdelavati žuriju se, istinito vživanje prave narodne radosti i slasti donaša; tak mu ogled na premilu dragu domovinu i njene sine vu dnu nutrine srdca žalost i tugovanje zbuđava, kojega korenje glibše je, neg da se negva žuhkoča i gorkost zmeriti more.”, u: Lj. Gaj, Kratka osnova horvatsko-slavenskoga pravopisanja, u: Riznica ilirska 1835-1985, prir. M. Šicel, Zagreb - Ljubljana 1985, str. 39.

${ }^{23}$ „Nas je negda jedna mati / Drága rodila / Z jednim nas je, Bog joj plati! / Mlékom gojila.”, u: Lj. Gaj, Horvatov sloga i zjedinjenje, u: Riznica ilirska..., op. cit., str. 88.

24 A. Mihanović, Horvatska domovina, u: M. Šicel, Hrvatski narodni i književni preporod (predgovor), u: Riznica ilirska..., op. cit., str. 86. 
bivanje nacijom asimilirano $\mathrm{s}$ bojom kože, spolom, rodom i vremenom u kojemu se rađamo - svim stvarima protiv kojih ne možemo ništa. I u tim 'prirodnim vezama' osjećamo ono što možemo nazvati 'ljepotom gemeinschafta' (zajednice). Drugim riječima, upravo zato što ih ne možemo birati te veze imaju aureolu nepristranosti ${ }^{25}$.

Prikazivanje domovine kao majke, njezina sinegdohizacija - majka utjelovljuje cijeli narod - pokazuje da uloga žene ima oblikotvornu ulogu u kulturnim konstrukcijama kolektivnih identiteta, pa tako i nacije. Riječima Yuval-Davis: „Žene su u kolektivnoj svijesti povezane s djecom i stoga s budućnosti kolektiviteta, kao i obitelji" ${ }^{26}$. Već i sam naslov Derkosova teksta Duh domovine med sinovima koji spavaju izdaleka priziva koncept domovine-majke. Za razliku od njega Štoos je posve izravan. U pjesmi Kip domovine vu početku leta 1831. Hrvatska je prikazana kao kraljica-majka zbog tuđinskoga jarma u crno zavijena. („Ovak se plače i briše lice, / Ter počne v goru iti z dolice / Tamo, gde negda Horvatski kralji / Svoje palače jesu imali, / Tamo, gde z mehnom sada pečine / Pokrite vidiš stare zidine, / Tamo je pošla tužna bogica, / Horvatske zemlje stara kraljica. / Ali kam ideš, predraga mati!?"'27)

Hrvatski se preporoditelji gotovo bez iznimke koriste ovim rodno-etničkim stereotipom ne bi li u narodu razvili osjećaj privrženosti prema naciji, ljubav kakva se inače ne gaji prema svakoj ženi, nego samo prema onoj koju nitko ne može sam birati. Upravo je stoga njezina „ljepota” sveta, izvorna i neupitna. Yuval-Davis ističe da se žena ne shvaća samo kao nositeljica „obiteljskoga” naslijeđa nego i časti imena zajednice. Iz tog razloga u zamišljanju valjanih rodnih funkcija preporoditeljima je svakako važno upozoriti na golemu opasnost od njihova iznevjeravanja. Pokazat ćemo to na primjeru Misli o jeziku Janka Jurkovića gdje se prokazuju majke/žene koje su sramota za svoje obitelji, ali i za cjelokupnu ilirsku zajednicu.

25 B. Anderson, Nacija: zamišljena zajednica, Razmatranja o porijeklu i širenju nacionalizma, prevele N. Čengić, N. Pavlović, Zagreb 1990, str. 130.

26 N. Yuval-Davis, Rod i nacija, prev. M. Paić Jurinić, Zagreb 2004, str. 64.

27 P. Štoos, Kip domovine vu početku leta 1831., u: Riznica ilirska..., op. cit., str. 47. 
Došlo je hvala Bogu vrieme, gdje mnoge matere smatraju kao njeku nesreću i kazan Božju, ako ih je zapalo, da moraju radjati djecu. O tih neću da govorim, to su - neću da reknem. A koje su malo bolje, one djecu, koju su rodile, ne ćedu da odgojivaju. Djeca se danas smatraju kao izmet, ili se postupa š nojm obično kao sa šimpanzi, s mačići ili drugim zvjerinjem. Konjaru se daju konji, volaru voli, njekomu mačke i psi - a dojci i pestinji daje se diete. Za mene je častno i sveto ime dojčino i ja sam ju imao, koja mi je druga mati bila; ali ne mogu nimalo da štujem matere, koja je narav pogazila, dostojanstvo svoje maternje samovlastno i sramotno povrgla, te bez svake nužde diete od sebe odmetnula, drugoj ga poklonila, za nj više ne pitala, ne skrbila - i u tom nikakova grieha ne vidjela! Zar takova djonova srdca ne osjetjaju, kada čedo svoje na grudih imadu, ono otajstveno obćenje, onu srodnost, onaj savez izmedju srdca djetinjega i svoga? (...) Ili možda misle, da je itko na svietu to djetetu podpuno nadomjestiti kadar? Da je to tako, to bi Bog možda bio drugčije uredio i ja ne znam, zašto onda ne bi mogla djeca roditi kao kruške, jabuke, bundeve itd.? - Najsvetija a mnogim valjda i najsladja dužnost matere jest, da diete na noge postavi. Dotle je njen upliv izključiv; otac se u to doba samo kadkada pokaže, da obljubi angjeosku nevinost, cviet ljepote, prve trake mudrosti, vrlosti-zrcalo zdrave duše na zdravu licu djetinjem: - posao majčin! ${ }^{28}$

Ovaj navod iz Jurkovićeva teksta jasno oslikava kako u nacionalističkom diskursu reproduktivna uloga žene ima iznimnu važnost i kako je njezina slika plod imaginacije muškog uma opsjednutog konstruiranjem identiteta zajednice. Žena je u toj predodžbi gigantska matica koja proizvodi pripadnike idealne zajednice. Prvi je uvjet koji se mora zadovoljiti da bi se uopće pripadalo nekoj zajednici samo rođenje. Za Jurkovića rađanje je djece „najsvetija i prirodna” zadaća svake žene; one su „stupovi zajednice”. Međutim bez obzira na njihovu moć kreiranja života, one u imaginaciji dominantno muških preporoditelja nisu stilizirane kao bogovi; upravo suprotno, sebe su preporoditelji autostilizirali kao polubožanstva koja navode gradnju Nad-identiteta.

28 J. Jurković, Misli o jeziku, u: Programski spisi hrvatskog narodnog preporoda, prir. M. Šicel, Zagreb 1997, str. 313-314. 
Srodno tome, Anne K. Mellor u studiji Romantizam i rod tvrdi da je žena u uvriježenom romantičarskom poimanju uglavnom plod maskulinih projekcija: „Kad iz bližeg promotrimo rodne implikacije romantičarske ljubavi, otkrivamo da ne prikazuju ženu kao vrijednog drugog; muški ljubavnici obično je uvlače u vlastitu narcističku projekciju"29. Jurković pak, u Mislima o jeziku, ženu samo na čas, dok se posvećuje dojenčetu, zamišlja kao vrijednog drugog. Imaginacija je opet podređena zagovaranju rodne politike koja se temelji na čvrstim podjelama prava i dužnosti. Biti ženom značilo je, također, biti strojem za proizvodnju materijalnih resursa kojima se nacija opslužuje. Prikazani rodni odnosi ključni su za narod u smislu biološke reprodukcije, ali i za kulturu u smislu obnavljanja njezinih simboličkih vrijednosti. Osnažujući u svojim tekstovima „prirodnost” rodnih podjela, hrvatski preporoditelji istodobno imaginacijom grade nacionalnu svijest koja se upravo temelji na prihvaćanju „prirodnosti” etničkih razlika.

Uz sve to, Jurković rodnu politiku prepleće s lingvističkom. Jedan od tri glavna štita hrvatskoga jezika je, prema njemu, „odgojenje domaće”. Majka je, u toj podjeli uloga, izravno odgovorna za komunikaciju na vernakularu.

Ona je dadilja duha djetinjega; ona počela svega života iz njega izvoditi imade; a ovamo spada i jezik. Diete imade biti danas sutra članom države, crkve, naroda, obitelji, a kao član ovoga ili onoga naroda označava ga ponajprije jezik; time se dakle uza dobra državljanina, krstjanina, takodjer za dobra narodnika pripravljati imade ${ }^{30}$.

Ova prispodoba o zadaći ,ilirske majke” zapravo je ideološka preporoditeljska strategija. Osim što simboliziraju potrebu za jedinstvom kolektiviteta, majke u priči o ilirskom identitetu igraju posve specifične rodne uloge. One moraju djecu poučiti vlastitom jeziku i upoznati ih $\mathrm{s}$,počelima svega života”, vjekovnim etničkim, državnim i religijskim

29 A. K. Mellor, Romanticism and Gender, New York - London, str. 25. Navedeno prema A. Day, Romanticism, London - New York 1996, str. 192.

30 J. Jurković, Misli o..., op. cit, str. 314. 
vrijednostima. Takva je žena konstrukt muškog uma koji je trbuhozborac još zamagljenije i nestalnije kategorije, nacije. Za taj je konstrukt osobito važno da žena kojoj su povjereni takvi sveti zadaci bude oličenje tradicije koja se ni u kojem slučaju ne smije ,izvrtati”. U tom se smislu ženi ne mogu tolerirati muški atributi; nipošto ne smije doći do zamjene muških i ženskih rola ${ }^{31}$. Žena u toj viziji nema što čitati, a kamoli pisati. Zanimljivo je da je i ženino čitanje u njoj prikazano kao problematičan obrazac ponašanja, odnosno žena koja čita, pomuškarčena je.

Pobogu braco! Na stolici od crljene kadife sjedi žena, lica muževna, ozbiljna i rekao bi nesmiljena. Odjevena je u dugačku jahaću haljinu od crna aksamita, izpod koje, kada ju zadigne, proviruju bile gaćice. Na glavi joj bieo visok mužki škrljak i oko njega zelena ovjesa. U ruci joj bič konjski, koga kadšto uzme i njime po sobi pucketa, te uza to nogom o nogu udara. A u ustih? - U ustih joj cigara! - Po sobi i kuhinji vrti se amo tamo čovjek s pripasanom pregačom, te sad iz sobe u kuhinju sad iz kuhinje u sobu; to sve sprema i itmitje, ručak pristavlja, piliće hrani itd. U njenoj sobi vidi se liepa knjižnica i do nje svakojake sbirke. Medju ostalimi starinami nalazi se pletivo iz najnovije stare dobe, preslica i vreteno, i kuhača - čime je još majka njena prela i kuhala. Ona skače, viče, svira, čita, puši, jaše, jede, spava, troši i gizda se; a on čuči, muči, igra na sviralu

31 Na to nas je upozorila i N. Badurina na primjeru Demetrove Teute gdje Dmitar i Teuta dijelom zamjenjuju rodno nametnute uloge: „Igra sa spolom jedina je Teutina krivnja zbog koje ona biva okrutno kažnjena. Teuta naime u nacionalnom i političkom smislu nije nikakva buntovnica, i ni po čemu ne narušava uspostavljene kolektivne vrijednosti; jednako kao i njezini suborci, ona čuva slobodu domovine za koju je spremna poginuti. Po toj je suglasnosti s vladajućom hijerarhijom ideja Teuta srodnica literarnog toposa žena-bojnica što se presvlače u mušku odjeću da bi se borile za poredak uspostavljen primarno muškim patrijarhalnim načelima; za domovinu ili za vjeru.", u: N. Badurina, Nezakonite..., op. cit., str. 62. „U okolnostima nacionalnointegracijskog procesa u kojima Demeter piše, poimanje muškobanjaste žene kao greške poprima političke konotacije, pa žena odjevena u muškarca postaje nužno loša vladarica, odnosno tiranka, a muškarac koji je zbog ljubavi spreman postati ženom i izdati svoju mušku prirodu, postaje izdajica domovine. Nacija, koja se tu prikazuje kao «priroda» (u smislu krvnog srodstva, «autohtonosti», tj. pupčane veze s teritorijem, i «prirodnih» granica), zapravo je skup strogih društvenih normi u kojima podjela rodnih uloga zauzima važno mjesto", ibidem, str. 64. 
njenu, s računi se znoji, trče, bdije, kuha i izplatjuje; čarape joj podvezuje, haljinu skapča, na konja ju penje. - Kakova je to žena? Kakov je to čovjek? (...) Sadri joj sa lica i tiela te sjajne dronjke, kojimi se je pokrila, da vidimo tko je i što je?

Kad ju prostota smjeri i okom svojim prostrieli, ono joj se gospodarsko lice njeno skruši i zasrami! Zastor joj pade, omače se po tielu od glave do pete, i nadje se, da je žena! - ona stara, ista istovetna, samo pokvarena žena!! To vam je emancipacia. Sada ste ju vidjeli. Idite, a ti slovaru moj dobri piši krupnimi i razgovietnimi slovi: emancipacia $=$ demoralizacia ${ }^{32}$ [isticanje I. Ž.].

U Jurkovićevoj se viziji podržavaju rodni stereotipi ključni za ,,ispravnu" socijalizaciju pojedinaca, taj neizostavni element nacionalne homogenizacije. Svaki član kolektiviteta treba znati gdje mu je rodno mjesto. Subjektivna Jurkovićeva interpretacija propisuje i kodificira tko je pravi muškarac, tko prava žena i što znači prijeći zacrtane granice. Budući da su žene imaginirane kao uporište kulturne međugeneracijske povezanosti, one personificiraju tradiciju i čast zajednice. Zato žene, kako ističe Nira Yuval-Davis, (...) „svojim ‘doličnim’ ponašanjem, 'doličnim' odijevanjem, (...) utjelovljuju granicu koja označava granice kolektiviteta"33. Vratimo li se još jednom konceptu imaginacije u tekstovima hrvatskih preporoditelja, primijetit ćemo da je doista na tragu romantičarskog koncepta imaginacije, jer pomiruje suprotnosti i disparatnosti; sličnosti s razlikama, opće s pojedinačnim, ideju sa slikom, individualno s reprezentativnim. Kao što Coleridge nastoji ujediniti dušu i biće stvaratelja-pjesnika i primatelja-čitatelja, tako i preporoditelji imaginaciju uprežu u oblikovanje nacionalnog identiteta koji bi se prirodno trebao preliti u sve članove nove-stare zamišljene zajednice.

\section{Imaginacija kao potvrda (prepo)rođenja nacije}

Svojevrsni déjà vu preporoditeljske kulturne politike dogodio se znatno poslije u lirici posvećenoj Domovinskom ratu. Iako je od početka

32 J. Jurković, Misli o..., op. cit., str. 312-313.

33 N. Yuval-Davis, Rod i..., op. cit., str. 65. 
Hrvatskog narodnog preporoda prošlo više od stoljeća i pol i unatoč drukčijem društvenom kontekstu u kojem nastaje ratno pjesništvo iz prve polovine 90 -ih 20 . st., u tom se segmentu suvremenog hrvatskog pjesništva ipak prepoznaje devetnaestostoljetna preporoditeljska neoromantičarska kulturna politika. Ona je prije svega vidljiva u oponašanju preporoditeljske ideologije nacionalnog identiteta kao svojevrsnog identiteta nad identitetima. Najsnažniji recidiv zasigurno je zabilježen u pjesništvu nastalom za vrijeme Domovinskog rata i neposredno poslije njega. Ovdje ćemo se osvrnuti na taj „rani” korpus ${ }^{34}$ (prva polovina 90-ih 20. st.) poezije koji se uglavnom referira na Domovinski rat. Tih je godina u Hrvatskoj sve zadobilo političko značenje pa i poezija, tako da je već u jeku rata niz eminentnih hrvatskih časopisa ponudio vlastite izbore ratne lirike ${ }^{35}$. Iako su svi ti izbori bili zaokupljeni iskustvom Domovinskog rata, u estetskom smislu oni se ni u kojem slučaju ne mogu strpati u isti koš. Uz pjesništvo ulogu ovjere nacionalnog identiteta obnašali su i drugi žanrovi, koji ostaju izvan okvira ovog rada, poput feljtona, javnih pisama, ratnih dnevnika, ali i mediji poput radija i TV-a. Upravo su mediji omogućili izvođenje poezije, bilo recitirane ili uglazbljene, u različitim prigodama (obljetnicama, komemoracijama) i postali poligonom širenja propagandnih antiratnih sadržaja. Prisjetimo se samo uglazbljene pjesme Drage Britvića Bože, čuvaj Hrvatsku, svojevrsnog remakea preporoditeljskih budnica kao što su Vukotinovićeva Nek se hrusti šaka mala ili Gajeva Horvatov sloga

34 Sintagma rani korpus odnosi se na pjesme koje su nastale kao neposredna reakcija na rat 1991. i 1992. te na kasniju produkciju uglavnom prikupljenu u različitim panoramama (Nad zgarištima..., op. cit.) i antologijama (Bratulićeva Lijepa naša, Hrvatske rodoljubne popijevke i pjesme iz 1991, Sanaderova i Stamaćeva U ovom strašnom času iz 1992, Petračeva Kip domovine iz 1996. i Mila si nam ti jedina... iz 1998.) do 1998. godine. Treba u tom smislu napomenuti da nisu uvršteni „mlađi” autori koji Domovinskom ratu pristupaju na znatno drukčiji način poput T. Bajsića (koji svoju zbirku Južni križ objavljuje 1998.), B. Dežulovića, T. Čadeža, V. Prekratića ili I. Simić Bodrožić. Niti je obuhvaćen širi korpus ratnog pjesništva rasut po različitim medijima (samostalne autorske i elektroničke knjige, časopisi, dnevne novine, poput Vjesnika ili Večernjeg lista, internetske stranice).

35 Da spomenemo samo neke: Krvatska, lirika ratne 1991, „Zrcalo” 1991, br. 1; Hrvatska 1991., „Quorum” 1991, br. 5-6, str. 6-25; Republika u ratu, „Republika” 1992, br. 3-4; Hrvatsko pjesništvo u ratu 1991/92, „Dometi” 1992, br. 1-2, str. 1-41; Dubrovnik u ratu, u: Dubrovnik, n. s., br. 2-3, Dubrovnik 1992. 
i zjedinjenje. U svakom slučaju i izvođene pjesme našle su svoje mjesto u oblikovanju nacionalne popularne kulture u 90-ima 20. st.

Prema riječima sastavljača antologije hrvatske suvremene ratne lirike U ovom strašnom času:

Ratna se lirika širila i 'izvanknjiževnim' kanalima: javnim glasilima, glazbenim priredbama, na književnim domjencima, elektroničkim medijima. Svi su oni pridonijeli afirmaciji hrvatske književne riječi, koja je na taj način 'izišla' iz ('zatvorenih'?) književnih i knjiških poredaka, te ušla izravno u uho i svijest današnjega hrvatskog čovjeka, izvrgnutoga poharama, duhovnoj pustoši i smrti. Naša se antologija obazirala i na tu činjenicu. Bilo nam je koliko do čiste pjesničke kakvoće, toliko i do mogućnosti što šire recepcije $\mathrm{e}^{36}$.

Iz posljednje rečenice doznajemo da su priređivači pjesme odabrali prema visokim estetskim kriterijima istodobno vodeći računa o što širem opsegu njihove recepcije. Međutim ti su kriteriji, barem kad je riječ o poeziji, teško uskladivi.

Nedjeljko Fabrio slično eksplicira metodologiju izbora Hrvatsko pjesništvo u ratu 1991/92:

Pružamo čitateljima zacijelo najneobičniji izbor iz hrvatske lirike s kojim se do sada susreo: od uobičajenog, akademskog pristupa takozvanoj pjesničkoj građi nije ovdje ostalo ništa. Pa ipak, umjetnički su rezultati nedvojbeni, gotovo izvanredni ${ }^{37}$.

Čini se da oba izbora na srodan način pomiruju nepomirljiva načela, objedinjujući na jednom mjestu, u tim prvim godinama devedesetih 20 . st., poeziju koja će podnijeti filtere kanona i onu kojoj će vrata kanona zauvijek ostati zatvorena. No, ovdje ćemo to proturječje ostaviti postrani, iako ćemo se i u daljnjem tekstu baviti uglavnom proturječjima. Tražit ćemo ih u suvremenoj poeziji Domovinskog rata, preciznije u njezinim strategijama ovjeravanja postojanosti državnosti i neupitnosti

${ }^{36}$ Predgovor, u: Uovom strašnom času. Antologija suvremene hrvatske ratne lirike, prir. I. Sanader i A. Stamać, Zagreb 1994, str. 8.

37 N. Fabrio, Uz izbor, „Dometi” 1992, br. 1-2, str. 1. 
samostalnosti nacije koje imaju štošta zajedničkog s preporoditeljskim taktikama imaginiranja nacionalnog identiteta. Nije ih teško pronaći u rečenom korpusu jer, kako je na jednom mjestu napisao Luko Paljetak, „rat i poezija, u svakom slučaju, tvore - krvavi oksimoron” 38 . Treba iznova napomenuti da se ovdje ni u kojem slučaju ne pretendira na sveobuhvatni prikaz građe ili sistematizaciju raštrkanog korpusa ratne poezije $^{39}$, srodnih izvandiskurzivnih praksi ${ }^{40} \mathrm{i}$ opis pojedinačnih poetika autora poput Zvonimira Mrkonjića čija se zbirka Put $u$ dalj u našoj znanosti o književnosti čita kao jedno od najboljih ostvarenja ratnog pjesništva. Iz okvira teme izlaze i problemi periodizacije.

Ponajprije oba koncepta imaginacije, preporoditeljski i onaj pjesnika Domovinskog rata, poput romantičarskog nisu lišena raznorodnih proturječja. Imaginacija i jednih i drugih „,kontaminirana” je ideološkom ulogom književnosti. Osim toga i jedni i drugi imaginaciju (književnost/ poeziju) uprežu u nešto što je potpuno oprečno izmaštanom: povijesna istina $^{41}$. Takvo bavljenje poviješću koje je u tekstu i ranije označeno kao stalno mjesto romantičarskog poimanja svijeta detektirali smo kao neza-

38 L. Paljetak, Poezija i rat, ,Republika” 1992, br. 9-10, str. 125.

39 U hrvatskoj znanosti o književnosti postoje tekstovi o korpusu (L. Paljetak, Poezija i rat, „Republika” 1992, br. 9-10, str. 124-125; Z. Kravar, Težišta hrvatskoga domoljubnog diskurza, ,Republika” 1992, br. 3-4, str. 192-197; B. Bošnjak, Hrvatsko pjesništvo u ratu 1991/92, „Dometi” 1992, br. 1-2, str. 39-41; A. Flaker, Hrvatska zaraćena književnost (1989.-1993.), „Republika” 1994, br. 9-10, str. 5-22; G. Rem, Slavonsko ratno pismo, Osijek-Slavonski Brod-Vinkovci, 1997.; S. Sorel, Isto i različito: Antologija i studija hrvatskog pjesničkog naraštaja devedesetih, Zagreb 2006.), ali još uvijek nemamo iscrpniju studiju koja bi bila posvećena isključivo poeziji Domovinskog rata.

40 Neke od njih su, naprimjer, Libertas konvoj za Dubrovnik, u kojem su sudjelovali brojni književnici, znanstvenici i umjetnici, koji je iz Rijeke krenuo 28.10.1991. i u Dubrovnik stigao 31.10.1991. s humanitarnom pomoći opkoljenom Gradu ili predstavljanje grafičko-poetskih svezaka Hrvatska 1991 iz edicije Zbirke Biškupić na Frankfurtskom sajmu knjiga 1991.

${ }^{41}$ Priređivač zbirke Nad zgarištima zvijezde, D. Rosandić, ističe da pjesme prikupljene u toj zbirci, bez obzira na to jesu li preuzete iz „Školskih novina”, „Radosti” ili Hrvatskog radija, i premda su u prvom redu literatura, mogu poslužiti kao rekonstrukcija povijesnih događaja: „Na temelju toga teksta moći će se rekonstruirati stvarna zbivanja (životna zbilja) koja je doživjela pjesničku preobliku. Susreti poezije i neposredne zbilje ostvaruju se u mnogim pjesmama.”, u: Nad zgarištima zvijezde, Hrvatska 1990/92, prir. D. Rosandić, Zagreb 1993, str. 6. 
obilazno opće mjesto tekstova preporoditelja, ali i suvremenih pjesnika Domovinskog rata u 90-ima 20. st. U svom tekstu Zaraćena književnost Flaker je ustvrdio da ,su se hrvatski književnici u golemoj većini odazvali pozivu povijesti”42. Doista pisci, etablirani, neafirmirani, čak i oni ,neprofesionalni" isprovocirani ratnom zbiljom nisu samo živjeli povijest, nego su je istodobno i pisali baš kao što su hrvatski preporoditelji davali obrise nacionalnom identitetu koji su istodobno gradili.

Imaginacija prošlosti u pjesništvu Domovinskog rata simptomatična je zbog sociopolitičkog konteksta užasa rata u kojem nastaje, u vrije$\mathrm{me}^{43} \mathrm{kad}$ se još uvijek dovodi u pitanje opstojnost samostalnosti nacije (Hrvatska nije međunarodno priznata do 15. siječnja 1992.). U tom je smislu ime nacije za pjesnike Domovinskog rata sveto jer svjedoči suverenitet domovine kako sadašnji tako i prošli. Iako je nacija već konstituirana, važno je stalno podsjećati svoje sugrađane na njezinu trajnost, pogotovo u trenutku njezina polusuverenog statusa. Rad na kulturnom pamćenju (Assmann) prisutan je, kao i u preporoditelja, već na nominalnoj razini gdje se samim ponavljanjem imena u naslovu niza pjesama ovjerava drevna opstojnost naroda. Uzmimo nasumce bilo koju od antologija pjesništva Domovinskog rata i vidjet ćemo da se ime nacije često ističe u naslovima pjesama (Hrvatska, Moja Hrvatska, Croatia, Lepa naša hrvatska zemla, Hrvatska govori, Croatia '91, Raspeta Hrvatska, Svijeće za Hrvatsku, Hrvatska je sveta zemlja, Naša Hrvatska, Dobro ti jutro, Hrvatsko!, Hrvatska 1991., Hrvatska na Božić 1991., Zemlja Hrvatska) ${ }^{44}$. Strastvenost priče o kontinuitetu imena još od srednjeg vijeka u stihovima pjesnika Domovinskog rata na tom je tragu posve očekivana: „Az opat Držiha napisah / Da uđe svima u svijest: / Ovdje, na ovom dijelu planete, / Hrvatska je bila, Hrvatske će biti, i Hrvatska jest!"'45

Ostavimo po strani razmišljanja u kojoj je mjeri kontinuitet oživotvoren u stihovima artificijelan; važno je da ideja o njemu ,uđe

42 A. Flaker, Hrvatska zaraćena književnost (1989.-1993.), „Republika”, br. 9-10, Zagreb 1994, str. 12.

43 Prve pjesme koje tematiziraju Domovinski rat datirane su u ljeto 1991.

${ }^{44}$ Naslovi pjesama pobrojani su iz ciklusa Hrvatska iz antologije: Nad zgarištima..., op. cit.

45 G. Rupčić, Nad zgarištima..., op. cit., str. 32. 
svima u svijest”. Imaginacija kao i u preporoditelja proturječno nije nešto što se opire materijalizaciji nego se s njom računa. Što recepcija ideje bude šira, njezin je utržak veći. Kontinuitet nacije je zato i zamišljan da podsjeti na simbole vlastitog identiteta: ime, slavnu hrvatsku povijest, kulturu i nezamislivu, sublimnu ljepotu domovine. Upravo to čini Radimir Zrilić u pjesmi Hrvatska govori:

Kažu da sam rodom iz Irana / Bila sam kraljevstvo u šestom stoljeću kod Krakova / Branila sam Bizantsko Carstvo od silnih Avara / i tako donesoh svoje ime i svoj duh / između Drave i Jadrana. / U svoju najljepšu domovinu / Dođoh kao ponosna kraljica među nezasitna carstva. (...) Nikad neću zaboraviti Sabor na Duvanjskom polju / i krunjenje svoga sina Tomislava za kralja hrvatskoga. / Zasja na hrvatskoj glavi kraljevska kruna / na radost cijelog hrvatskog naroda / i osta kao ponos kraljeva / Držislava, Krešimira, Zvonimira... // Moji moćni plemići Šubići, Bribirski / kasnije prozvani Zrinski i knezovi krčki Frankopani / stoljećima su branili moje posjede, / stoljećima su branili moje kraljevske slobode / dajući često svoje živote i glave / ne dajući tuđinu, ne dajući Turčinu / da zatre moje kraljevsko i hrvatsko ime ${ }^{46}$.

Takvim simbolima poput imena podcrtava se kontinuitet povijesnih prava, ali i samostalnosti države koja je proturječno tu od pamtivijeka, ali je i novonastala uzme li se u obzir autonomija i suverenost zadobivene danom njihova priznanja 15. siječnja 1992. Oba autora smatraju da je nacija postojala još u srednjem vijeku i bila samostalna, te da je samostalnost samo privremeno izgubila u bespućima povijesti da bi je opet „preporođenu” povratila kao vlastito važno identitetsko uporište. Legitimitet i objektivnost vlastitog govora oba lirska subjekta priskrbljuju posuđivanjem ,tuđih identiteta”, prvi posuđujući identitet autora Baščanske ploče, a drugi imaginirani identitet vlastite nacije u liku samostalne žene ponosne kao kraljice: („Povijesna je istina, nikad silom nisam pokorena / sad sam opet samostalna i ponosna kao kraljica / među slobodnim državama. / OVO JE MOJA NAJLJEPŠA DOMOVINA" ${ }^{47}$ ).

46 R. Zrilić, Hrvatska govori, u: Nad zgarištima..., op. cit., str. 22-23.

47 Ibidem, str. 23. 
Konstrukt žene-domovine u 90-ima nije istovjetan onomu iz vremena hrvatskog narodnog preporoda, ali određeni se stereotipi ipak ponavljaju. Ovdje je ona reprezentirana kao žena koja silom nikad nije pokorena, ali i kao ponovno samostalna i ponosna kraljica što ipak sugerira da je nekad bila nesamostalna. Međutim od te je proturječnosti puno važnije da je u navedenim stihovima nacija predočena ne kao bilo kakva žena nego kraljica. U skladu s ratnim okolnostima žena koja utjelovljuje domovinu postaje nositeljicom obično neženskih uloga. Ako je kraljica, to znači da je prva u vrsti, osoba na kraljevskom položaju. Na tom se tragu može čitati i ova predodžba žene kao mitološke junakinje u Mrkonjićevoj pjesmi Hekuba: ,Ako je Robinja bila jedan od arhetipova hrvatske sudbine, danas je to sigurno Hekuba. Već mnogo godina poznajem jednu ženu koja je nedavno izgubila oba sina te je u zbilji morala preuzeti ulogu Hekube"48. Preuzimanje neženskih uloga isključivo u nemogućim okolnostima rata dodatno pojačava protuprirodnost žene-ratnice, Demetrove amazonke Teute. Nira Yuval Davis u svojoj studiji Rod $i$ nacija cijelo jedno poglavlje posvećuje rodnom karakteru vojski i ratova ističući kako jasna spolna podjela rada u ratu na trenutak iščezava ${ }^{49}$. Superheroine poput Mrkonjićeve obične žene, Katarine Liban iz Mokošice koju zbilja tjera da preuzme ulogu mitske -junakinje Hekube, majke koja gubi sinove, ali ih i osvećuje, simboliziraju naciju. U određenom smislu takva romantička predodžba ženejunakinje, svojim antiratnim krikom izjednačene s muškarcem, barem simbolički sve pripadnike nacije uključuje u ,istu” borbu. Kao kulturni simbol kolektiviteta žena je često prikazana u ambivalentnom položaju, s jedne strane obnaša svoje tradicionalne, ,prirođene" uloge (majka, čuvarica ognjišta, obitelji, vjere) a s druge one nametnute ugrozom da joj se te funkcije oduzmu. Ona postaje ratnicom jer joj je uskraćen onaj kulturno reproducirani identitet žene kao simboličkog potpornja zajednice. Jedino u takvoj graničnoj situaciji dopuštene su joj transgresivne „on/ ona” uloge koje možemo pronaći i u ovim stihovima: „Ja sam roditeljica i hraniteljica. / Ja sam tvoja ljubav: djevojka i / zaručnica, i žena i vjernica. / Ja sam ratnica, mučenica, uznica / i patnica: brojim korake po rubu i /

48 Z. Mrkonjić, Hekuba, „Republika” 1992, br. 1-2, str. 7.

49 Usp. N. Yuval Davis, Rod i..., op. cit., str. 123. 
strepim da se ne polome niti između biti i sniti. (...) Ja sam Jedina / koju se ne zaboravlja: / amanet, / oporuka, znamen / i Amen"50.

I u drugim tekstovima domovinu utjelovljuje „osobita” žena, heroina kanonske književnosti, npr. vila Dubravka u Paljetkovoj pjesmi Dubrav$k a$ a. d. 1991. Slično su stilizirane i majke u pjesmi Hrvatska majka Marije Peakić Mikuljan, Majka Hrabrost Arsena Dedića ili Ponosna mati Jure Karakaša. One su i ovdje kao i u hrvatskih preporoditelja reprezentirane kao nositeljice identiteta nacije. I ovdje svojim svojstvima reprezentiraju ,čast zajednice”, doduše sada države. Međutim, u 90-ima 20. st. žena uz one uvriježene društvene uloge roditeljice, hraniteljice, zaručnice, supruge i vjernice obnaša i ulogu ratnice (Tolj). Njezin je prikaz prilagođen novim okolnostima u kojima se „stara priča” još iz vremena izgradnje nacionalnog identiteta treba reprizirati. Majčinstvo, nesebična i najstrašnija žrtva odašiljanja vlastite djece u rat/smrt, sve se te uloge metonimijski pripisuju naciji. Iako se ženi u ratnoj poeziji 90-ih 20. st. pridaju i neki novi atributi (ratnica, uznica, mitska junakinja) u odnosu na preporoditeljski identifikacijski kod, ipak se ne može reći da je ona predočena kao subjekt koji „,rame uz rame” s muškarcem sudjeluje u borbi za nacionalnu autonomiju.

U preporoditeljskom ,pismu” i ,ratnom pismu” poezije Domovinskog rata razaznaju se i srodne strategije ponavljanja određenih motiva kojima se radi kako na oblikovanju individualnog tako i na ovjeravanju kolektivnog identiteta nacije, i to na taj način da se individualni uvijek pokorava kolektivnom. Prije svega ceremonijalno se ponavljaju motivi zajedničke drevne junačke prošlosti, istaknutih povijesnih osoba, sloge $^{51}$, Hrvatske kao predziđa kršćanstva ${ }^{52}$. Kad je riječ o povijesti, i u poeziji Domovinskog rata interpretiraju se točno određeni događaji

50 I. Tolj, Anima Croatorum, u: Mila si nam ti jedina... Hrvatsko rodoljubno pjesništvo od Bašćanske ploče do danas, prir. J. Bratulić, S. Damjanović, V. Brešić i B. Petrač, Zagreb 1998, str. 503-504.

51 J. Ravlić, „Ej, Hrvati, vi oko zelene Drave, / tihog Dunava, duge Save, plodne / Slavonije, brežuljkastog Zagorja / Međimurja, Banije, krševite Dalmacije / kristalnih otoka, modre Neretve, drevnog Dubrovnika / svi složno u boj sada ili nikada.”, u: Nad zgarištima..., op. cit., str. 24. I. Svetić, ,Jedno smo srce. / Čvrste nam šake. / Sloga je spas. / Trpjesmo dugo. / Pišemo povijest. / Sada je čas.”, ibidem, str. 26.

52 J. Karakaš, „Oduvijek ste bili brana, / Zid kršćanstva na Balkanu, / Štitili ste svojom krvlju / Tu Evropu, staru damu.”, u: Nad zgarištima..., op. cit., str. 25.; B. 
iz povijesti, uvijek obilježeni romantičarskom žudnjom za apsolutnom istinom. Zato nije nimalo neobično da Šoljan u pjesmi Dvanaestorica 1102. poseže baš za događajem iz prošlosti u kojem narod ostaje bez svoje neovisnosti, gubeći na taj način međunarodni identitet. Riječ je o poznatom sporazumu u hrvatskoj povijesti poznatom pod nazivom Pacta Conventa iz 1102. kojim je dvanaest predstavnika hrvatskog plemstva prihvatilo ugarskog kralja Kolomana za hrvatskog vladara, poslije smrti posljednjeg hrvatskog kralja Petra Svačića na Gvozdu. Šoljan ovako zamišlja dvanaest hrvatskih plemića koji su iznevjerili nešto tako sveto kao što je tisućgodišnji ,duhovni i moralni integritet” naroda: „otpisali desetak stoljeća ko ništa, / svaki, približno, po stoljeće. // Brže bolje su odjahali u tamne šume Gvozda, / šutke - snijeg je pršio među granama jela. // Bilo ih je dvanaest, kao apostola, / ali nikakvoga boga nisu imali na čelu. // Mala se djeca rađaju s njihovim tetoviranim potpisom / na plećki" 53 . Ostavljamo postrani vjerodostojnost tog sporazuma koju danas povjesničari propituju. Znamo da su i preporoditelji često opjevavali događaje čija se ,,autentičnost” dovodi u pitanje. Dovoljno je spomenuti sveprisutni motiv Grobničke bitke u preporoditeljskim tekstovima. Puno je važnije na ovom mjestu istaknuti da je otklizavanje u mitsku narodnu prošlost u funkciji učenja važnih lekcija iz povijesti. Hrvatskih plemića je bilo 12 kao apostola, ali njihov je čin predstavljen ne samo kao nenavođen Božjom Providnošću nego kao ,grijeh koji je navukao prokletstvo na cijeli rod". Religijske identifikacije su uopće dominantne u pjesmama posvećenim Domovinskom ratu i one su trebale osnažiti nacionalnu identifikaciju.

Domovina se u mnogim pjesmama sakralizira, ona se doslovno naziva svetom zemljom ${ }^{54}$. Uspoređuje se i s Isusom žudeći proizvesti

Biletić, „Uokolo uredno žive mirisni, usporedni svjetovi, a gustoća povijesnih riječi i mi, kao uvijek na predziđu.", Mila si nam ti jedina, str. 506.

53 A. Šoljan, Dvanaestorica 1102. u: Krvatska, lirika ratne 1991, „Zrcalo” 1991, br. 1 , str. 5 .

${ }^{54} \mathrm{Lj}$. Car Matutinović, Otvori se sveta zemljo Hrvatska (pjesma Otvori se sveta zemljo Hrvatska u Dometi, XXV., br. 1-2, Rijeka 1992., str. 19); J. Karakaš, Hrvatska je sveta zemlja (pjesma S Velebita klikće vila u Nad zgarištima..., op. cit., str. 25); J. Pejkić, Pale te, o zemljo sveta (pjesma Feniks u Nad zgarištima..., op. cit., str. 27); J. Karakaš, Hrvatska je za me sveta (pjesma Hrvatska je sveta zemlja u Nad zgarištima..., op. cit., str. 25). 
sliku Hrvatske kao nevine i nepravedno razapete stradalnice. Brešićev izbor ratne lirike Krvatska... je doslovce uprizoruje na taj način slikom Krista Dimitrij Popovića na naslovnici. Motiv se isticao i u naslovima pjesama (Raspeta Hrvatska Mire-Marije Andrun, Razapeta na križu Franje Friščića, Hrvatska Golgota Ane Ivelje, Horvatski Jezuš Božice Jelušić, Krist u Hrvatskoj Krešimira Šege, itd.). Dakle, biblijski motivi i uopće religijska identifikacija u ranom pjesništvu Domovinskog rata povezuje se s nacionalnom, i to obično da bi je legitimirala. Na primjer, u ranije spomenutoj pjesmi Hrvatska govori religija je uporište za ojačavanje nacionalnog identiteta (,Bog mi dade Jadransko more / za vječnoga saveznika, / kao zavjetni kovčeg Židovima / i ono postade nesavladiva prepreka / svim mojim neprijateljima. // Božanski blagoslov za vjernost crkvi / Posla na kneza Branimira / I sav narod hrvatski papa Ivan VIII / Dante će se u svojim stihovima / Diviti bogu vjernim Hrvatima"55. Božji blagoslov, kojim je papa Ivan VIII. nagradio kneza Branimira u 9. st. za njegovu vjernost Crkvi, priskrbljuje se i za Hrvate u ratnoj 1991. Trajnošću povijesne religijske identifikacije potvrđuje se istodobno i postojanost nacionalne. Baš kao što je lako podnijeti najveće žrtve za majku, tako je lako i identificirati se s identitetom naroda čija je borba za slobodu i autonomnost navođena Božjom Providnošću. Važno je dakle da se razazna čija vjeroispovijest u Domovinskom ratu „ima pravo”, bez obzira na to što to nije nimalo u skladu sa zajedničkom etikom kršćanske religije Hrvata i Srba. Kao u pjesmi Hrvatska govori i u Slavičekovoj se pjesmi Moj Karol Wojtyla prisvaja Božji blagoslov posredstvom pridobivanja tada živućeg katoličkog pape Ivana Pavla II. na „,našu stranu”: ,Veliki su Pape oduvijek bili na našoj strani / A posebno moj Poljak, Njegova Svetost Wojtyla / Blizak je našoj kobi, prkosu, rani / Možda i zato što je pjesnik, miljenik vila" ${ }^{96}$. Poistovjećivanje odanosti religiji s odanošću naciji opet je u službi ,pokorene imaginacije” koja ima zadaću uskrsnuti prastare i stvoriti nove pričine. Tako je i Genij koji utjelovljuje pjesnika rane ratne poezije uhvaćen u klopku pomirenja nepomirljivog: individualnog i kolektivnog identiteta, individualne

55 R. Zrilić, Hrvatska govori, u: Nad zgarištima..., op. cit., str. 22.

56 M. Slaviček, Moj Karol Wojtyla (Rat u Hrvatskoj 1991), u: Krvatska, Lirika ratne 1991, „Zrcalo” 1991, br. 1, str. 8. 
imaginacije i racionalnog odgovornog odaziva povijesti (,,Ne, sonet nije za bubnjeve i bojne stjegove i trube stvoren / Ali je pridatan da u dane kada domovi i duše gore" ${ }^{57}$ ), imaginiranja romantičarske mitske figure žene-Domovine i kodiranja njezinih rodnih uloga. Na kraju zamijetit ćemo da i hrvatsko pjesništvo devedesetih i preporoditeljski tekstovi daju imaginaciji iznimnu moć. Ona je na najvišem mjestu na njihovim vrijednosnim ljestvicama, jer je bez nje nemoguća proizvodnja mitova ili poželjnih obrazaca ponašanja. Imaginacijom se po potrebi brišu proturječnosti i podjele ili zanemaruju te poništavaju drugosti ili se i one upotrebljavaju u svrhu generiranja hegemonističkih simbola ili organskog jedinstva kulture/nacije. Zato ideologija tog nadidentiteta, i u jednim i u drugim tekstovima, nedvojbeno diktira u kojoj će mjeri imaginacija biti ili ne u izravnoj vezi s drugim identitetima poput religijskog, obiteljskog ili pak rodnog. Treba još jednom reći da je u svim tim tekstovima riječ o „dvoličnoj” neoromantičarskoj imaginaciji koja ni u kojem slučaju nije lišena proturječja, nego je duboko njima ispremrežena. Na kraju, parafrazirajući naslov Mićanovićeve pjesme Job (hrvatsko pjesništvo devedesetih), razvidno je da i preporoditeljima $\mathrm{i}$ hrvatskim pjesnicima Domovinskog rata ustrajna vjera u imaginaciju omogućuje zamišljanje identitetskih uporišta bilo u rodu, religiji ili naciji. U konačnici, to ,jobovsko" slijeđenje imaginacije, u romantičarskom smislu, izmišlja nove svjetove i njima gradi temelje zajednice.

\section{Literatura}

Abrams M. H., The Mirror and the Lamp: Romantic Theory and the Critical Tradition, London - Oxford - New York 1971.

Anderson B., Nacija: zamišljena zajednica. Razmatranja o porijeklu i širenju nacionalizma, prevele N. Čengić i N. Pavlović, Zagreb 1990.

Assmann A., Rad na nacionalnom pamćenju. Kratka istorija nemačke ideje obrazovanja, Beograd 2002.

Badurina N., Nezakonite kćeri Ilirije, Hrvatska književnost i ideologija u 19. i 20. stoljeću, Zagreb 2009.

Balibar É., We, the People of Europe? Reflections on Transnational Citizenship, Princeton - Oxford 2001.

\footnotetext{
57 M. Slaviček, Hrvatski sonet, u: Mila si nam ti jedina..., str. 414.
} 
Bowra M., The Romantic Imagination, London 1961.

Clark T., The Theory of Inspiration, Composition as a crisis of subjectivity in Romantic and post-Romantic writing, Manchester - New York 2000.

Day A., Gender and the Sublime, u: Romanticism, London - New York 2004, str. 183-202.

Demeter D., Izabrana djela, prir. N. Batušić, Zagreb 1997.

Fabrio N., Uz izbor, „Dometi” 1992, br. 1-2, str. 1.

Ferber M., Romanticism. A Very Short Introduction, New York 2010.

Fowler R., Imagination, u: A dictionary of modern critical terms, ur. idem, London, Henly - Boston 1973, str. 93-96.

Hrvatski narodni preporod, Ilirski pokret, ur. J. Šidak, V. Foretić, J. Grabovac, I. Karaman, P. Strčić, M. Valentić, Zagreb 1988.

Hobsbawm E., Uvod: Kako se tradicije izmišljaju, u: Izmišljanje tradicije, ur. E. Hobsbawm, T. Ranger, prev. S. Glišić, M. Prelić, Beograd 2002, str. 5-25.

Jurković J., Misli o jeziku, u: Programski spisi hrvatskog narodnog preporoda, prir. M. Šicel, Zagreb 1997, str. 313-314.

Mila si nam ti jedina... Hrvatsko rodoljubno pjesništvo od Bašćanske ploče do danas, prir. J. Bratulić, S. Damjanović, V. Brešić i B. Petrač, Zagreb 1998.

Nad zgarištima zvijezde, Hrvatska 1990/92, prir. D. Rosandić, Zagreb 1993.

Rakovac D., Svět pismeni i nepismeni, Danica ilirska, 13. studenoga 1847, br. 46, str. 184.

Riznica ilirska 1835 - 1985, prir. M. Šicel, Zagreb - Ljubljana 1985.

U ovom strašnom času, Antologija suvremene hrvatske ratne lirike, prir. I. Sanader i A. Stamać, Zagreb 1994.

Yuval-Davis N., Rod i nacija, prev. M. Paić Jurinić, Zagreb 2004.

Žanić I., Simbolični identitet Hrvatske u trokutu raskrižje-predziđe-most, u: H. Kamberović, Historijski mitovi na Balkanu, Sarajevo 2003, str. 161-202. 